THE PEDAGOG ICAL STATE 

S A M K A P L A N

\section{The Pedagogical State}

Education and the Politics of National Culture in Post-I 980 Turkey

STANFORD UNIVERSITY PRES S

STANFORD, CALIFORNIA 2006 


\begin{abstract}
(C) Stanford University Press
Stanford, California

(C) 2006 by the Board of Trustees of the Leland Stanford Junior University. All rights reserved.
\end{abstract}

No part of this book may be reproduced or transmitted in any form or by any means, electronic or mechanical, including photocopying and recording, or in any information storage or retrieval system without the prior written permission of Stanford University Press.

Printed in the United States of America on acid-free, archivalquality paper

Library of Congress Cataloging-in-Publication Data

Kaplan, Sam, I958-

The pedagogical state: education and the politics of national culture in post- 1980 Turkey / Sam Kaplan.

p. $\mathrm{cm}$.

Includes bibliographical references and index.

ISBN 0-8047-5432-2 (cloth: alk. paper)-

ISBN o-8047-5433-० (pbk.: alk. paper)

I. Nationalism and education-Turkey. 2. Education and state-Turkey. I. Title. II. Title: Education and the politics of national culture in post- 1980 Turkey.

LC94.T9к374 2006

$379 \cdot 56 \mathrm{I}-\mathrm{dc} 22$

2006004304

Typeset by G\&S Book Services in Io/I4 Janson

\title{
Another Brick in the Wall (Part 2)
}

Words and Music by George Roger Waters

(C) 1979 Roger Waters Music Overseas Ltd.

Warner/Chappell Artemis Music Ltd.

All Rights Reserved. Used with Permission. 
To Alex and Eytan, the next generation To Tania Forte (1959-2005), their mother 
